Women in Mathematics : Celebrating the Centennial of the

\title{
Mathematical Association of America
}

Kennedy, Juliette

2019-06-01

Kennedy , J 2019 , ' Women in Mathematics : Celebrating the Centennial of the

Mathematical Association of America ' , Isis , vol. 110 , no. 2 , pp. 427-428 . https://doi.org/10.1086/703808

http://hdl.handle.net/10138/317187

https://doi.org/10.1086/703808

acceptedVersion

Downloaded from Helda, University of Helsinki institutional repository.

This is an electronic reprint of the original article.

This reprint may differ from the original in pagination and typographic detail.

Please cite the original version. 
Janet L. Beery, Sarah J. Greenwald, Jacqueline A. Jensen-Vallin and Maura B. Mast (Editors). Women in Mathematics: Celebrating the Centennial of the Mathematical Association of America. (Association for Women in Mathematics Series, 10.) xii + 405 pp., bibl., Index. Switzerland: Springer, . \$139.00 (cloth), ISBN 9783319666938.

We have come a long way since the publication of E.T. Bell's Men of Mathematics (Simon \& Schuster 1937), a book whose title says it all. Or have we? One wishes that the very timely book under review was not needed; that being a woman mathematician was nothing to take notice of. Perhaps that time is not far off.

Women in Mathematics (whose subtitle belies the volume's international scope) traces the arc of women's experience of, and contributions to, mathematics over the course of twenty-one fascinating essays, beginning with an early history of Girton College (Cambridge), which opened its doors to five women in October of 1869. 
As one would expect, the news from these early years is mixed. A number of Girton alumni would go on to have extraordinary careers, even so that Girton alumni were denied Cambridge degrees until 1921, when they were granted titular degrees, i.e. degrees in name only, conferring no membership or voting privileges; and almost three decades would pass before women were admitted as full members of Cambridge in 1948. As for the Royal Society, it did occasionally publish the work of women scientists; but it opened its doors to women as members only in 1945 , where previously women were thought to have been disqualified from membership by marriage, which diminished a woman's legal status according to the common law at the time. Among the Girtonians whose story is told in this first essay is that of Charlotte Scott, who earned first class honors on the 1880 Mathematical Tripos, a fifty-hour (!) ordeal spread over nine days; was awarded her DSc degree in 1885 , becoming the second woman in Europe (after Sonia Kovalevskaya) to earn a doctorate in 
mathematics; and who emigrated to America in 1885, going on to become the first head of the mathematics department at Bryn Mawr. Another is Sarah Marks, who was denied membership in the Royal Society on the basis of her marital status (see above), but was nevertheless awarded the 1906 Royal Society Hughes medal for her work on electrical arcs and sand ripples. Other Girtonians of that cohort would also go on to have solid careers in mathematics, albeit facilitated by emigration, e.g. to South Africa (Kate Knight Gale), and by nonmarriage.

Of the many women whose biographies are so movingly told in the volume, one in particular stays in mind. This is the story of Emil Artin's first graduate student (in Germany) Käte Hey, as told by Della Dumbaugh and Joachim Schwermer in their essay "Käte Hey and Margaret Matchett---Two Women PhD Students of Emil Artin." Hey's 1927 thesis Analytische Zahlentheorie in Systemen hypercomplexer Zahlen contained results that were described by Artin in his official report on the thesis as "nice and very 
remarkable," including a theorem closely related to what came to be known as the Albert-Brauer-Hasse-Noether theorem (modulo some rephrasing on the part of Max Zorn and Max Deuring). Hey wanted to pursue an academic career but was discouraged from doing this by her father, for financial reasons. Instead she qualified as a teacher, teaching in secondary school for a time before leaving mathematics altogether upon her marriage in 1932. There her history ends---as far as mathematics goes anyway. She had four children; she died in 1990.

Empirical data is brought forward in two essays, Judy Green and Jeanna LaDuke's “Pioneers: The Pre-1940s PhDs" and Margaret Murray's "Toward a Documentary History of American Women PhDs 1940-1959." A nicely granular study of that transitional generation of American women mathematicians, one learns in Murray's piece that the steady increase in the small numbers of female PhDs in the 1940s was followed by a marked decline in these during the boom years of the fifties and sixties, when women 
earned fewer PhDs in mathematics as a percent of the total awarded, than they had at the turn of the century. Why? Murray asks.

Part II of the book is devoted to individual biographies, including those of Florence Nightingale, Mina Rees and Emmy Noether. Many have perhaps read about Emmy Noether, but Colin McLarty's piece brings her alive in way one may not have seen, both as the powerful mathematician she was, but also as a powerful, proud, and compassionate human being.

The last section of the book presents various American educational efforts to address the persistent lack of diversity in the profession. One had hoped to see some empirical studies also here; on the other hand the papers are a delight to read.

The volume takes a fairly light touch on the issues, on the whole, and perhaps this is appropriate. Mathematicians, in general, want 
to promote talent where ever and in whomever they see it. On the other hand, we are not so far from less enlightened times---any woman who graduated from almost any university in the last twenty years can attest to that.

My bio:

Juliette Kennedy is Associate Professor in the Department of Mathematics and Statistics of the University of Helsinki. She works in logic, set theory, and foundations of mathematics. 